\title{
Mitigation Potential and Cost in Tropical Forestry - Relative Role for Agroforestry
}

Willy R. Makundi and Jayant A. Sathaye

Lawrence Berkeley National Laboratory

Lawrence Berkeley National Laboratory, 1 Cyclotron Rd, Berkeley, CA 94720, Tel: 510-486-6852, Fax: 510-486-6996,*e-mail: WRMakundi@1bl.gov

Running Title: Mitigation Potential in Tropical Forestry and Agroforestry

\begin{abstract}
This paper summarizes studies of carbon mitigation potential and costs of forestry options in seven developing countries with a focus on the role of agroforestry. A common methodological approach known as COMAP (Comprehensive Mitigation Assessment Process) was used in each study to estimate the potential and costs between 2000 and 2030. The approach requires the projection of baseline and mitigation land-use scenarios derived from the demand for forest products and forest land for other uses such as agriculture and pasture. By using data on estimated carbon sequestration, emission avoidance, costs and benefits, the model enables one to estimate cost effectiveness indicators based on monetary benefit per $\mathrm{C}$, as well as estimates of total mitigation costs and potential when the activities are implemented at equilibrium level. The results show that about half the mitigation potential of $6.9 \mathrm{G} \mathrm{tC}$ (an average of $223 \mathrm{Mt} \mathrm{C}$ per year) between 2000 and 2030 in the seven countries could be achieved at a negative cost, and the other half at costs not exceeding $\$ 100$ per t $\mathrm{C}$. Negative cost indicates that non-carbon revenue is sufficient to offset direct costs of about half options. The agroforestry options analyzed bear a significant proportion of the potential at medium to low cost per $\mathrm{t} C$ when compared to other options. The role of agroforestry in these countries varied between 6 and 20 percent of the mitigation potential, though the options are much more cost effective than most due to the low wage or opportunity cost of rural labour. Agroforestry options are attractive due to the large number of people and potential area currently engaged in agriculture, but they pose unique challenges for carbon and cost accounting due to the dispersed nature of agricultural activities in the tropics, as well as specific difficulties arising from requirements for monitoring, verification, leakage assessment and the establishment of credible baselines.
\end{abstract}

Keywords: Carbon offsets, COMAP, Cost effectiveness, Greenhouse gases, LULUCF potential 


\section{Introduction}

Terrestrial ecosystems play an essential role in the global carbon cycle. ${ }^{1}$ Tree growth serves as an important means to capture and store atmospheric carbon dioxide in vegetation, soils and biomass products. This form of carbon storage may not be permanent due to the likelihood of release by anthropogenic and natural disturbances or processes. ${ }^{2}$ However, the use of biomass products from sustainably managed forests to substitute for unsustainably produced harvested forest products or fossil-based products, or for fossil fuels, offers an opportunity for the permanent removal of GHG emissions from the atmosphere.

A recent assessment of the land use, land-use change and forestry (LULUCF) options suggests that the total global technical potential for biologically feasible afforestation and reforestation activities between 1995 and 2050 will average between $1.1-1.6 \mathrm{G} \mathrm{t} \mathrm{C/} \mathrm{yr}$, of which 70 percent will be in the tropics (IPCC, 2000a). An assessment of potential sequestration from additional activities in improved land use management and other land-use changes suggests that by 2010 , it may exceed $1.3 \mathrm{Gt} \mathrm{C/} \mathrm{yr}$, rising to about $2.5 \mathrm{Gt} \mathrm{C/} \mathrm{yr} \mathrm{by} 2040$ (IPCC, 2000b). The LULUCF technical potential for carbon sequestration and emission reduction estimated by the IPCC Report represents about a sixth of the estimated $6.3+-0.6 \mathrm{Gt} \mathrm{C}$ average annual carbon emissions from fossil fuel combustion and cement production (IPCC, 2000c). However, given the economic, social, and institutional barriers facing these options, the achievable potential from the LULUCF options may be considerably lower than the technical potential.

The technical potential for carbon sequestration potential reported in the IPCC Second Assessment Report (SAR) amounts to between 8.7 to 12.1 years worth of aforementioned average annual carbon dioxide emissions from fossil fuel combustion and cement production between 1995 and 2050 (Brown et al, 1996). Of this potential, 40-61 Gt C is estimated to be in tropical countries plus China represent between 6.4 to 9.7 years of carbon emissions from fossil fuel use and industrial emissions.

In general, the forestry mitigation potential varies across countries depending on the suitability of their land for forestation, the levels of current and future carbon dioxide-emitting activities, potential for substitution in carbon-intensive services and products, and of other options for

\footnotetext{
${ }^{1}$ The IPCC reports an estimated $1146 \mathrm{Gt} \mathrm{C}$ stored within the 4.17 billion hectares of tropical, temperate and boreal forest areas,

a third of which is stored in forest vegetation (IPCC, 2000c). Another $634 \mathrm{Gt} \mathrm{C}$ is stored in tropical savannas and temperate grasslands.

${ }^{2}$ Carbon emissions from land-use change worldwide during 1989-98, for instance, are estimated to be 1.7 t. $0.8 \mathrm{Gt} \mathrm{C/} \mathrm{yr}$
} 
reducing deforestation. Based on a recent survey of emissions and very preliminary sequestration estimates in the energy and forestry sectors of select developing countries (Sathaye and Ravindranath, 1998), it seems that the estimated mitigation potential in LULUCF far exceeds the emissions from the respective energy sectors (see Table 1).

The amount of time it takes to tap this potential depends on the mix of forestry mitigation options that is suited to each country. Reducing deforestation potentially could be achieved over a short time span if appropriate socio-economic incentives were established and maintained to halt activities that cause deforestation and the misuse of forest resources. Forestation would take longer simply because tree growth takes many years to reach maturity, depending on species and site conditions. One of the forestation options in the tropics, which is likely to be very attractive, is agroforestry since it combines wood production with agricultural or pastoral activities.

Agroforestry is attractive on account that it intervenes the carbon emission cycle at many points. First it sequesters carbon in vegetation and possibly in soils depending on the pre-conversion soil C. Secondly, the more extensive use of the land for agricultural production reduces the need for extent of slash and burn or shifting cultivation, which contributes significantly, to deforestation. Thirdly, the wood products produced under agroforestry serve as substitute for similar products unsustainably harvested from the natural forest. Also, to the extent that agroforestry increases the income of farmers, it reduces the incentive for further extraction from the natural forest for the purpose of income augmentation.

A number of scientific and policy questions are being asked in international and national debates by - national governments and climate change negotiators, potential investors in GHG mitigation activities, local communities and other stakeholders. How much additional carbon stock might be created, and how much emissions reduction might be achieved through these mitigation activities? What is the cost effectiveness and total cost of implementing these mitigation activities? Which forestry mitigation options are the most important for developing countries, and local communities?

This paper addresses some of these issues through a summary evaluation of the results from studies in seven countries - Brazil (Fearnside, 2001); China (Deying et al, 2001); India (Ravindranath et al, 2001); Indonesia (Boer, 2001); Mexico (Masera et al, 2001); Philippines (Lasco et al, 2001) and Tanzania (Makundi, 2001), In addition, we highlight the relative potential for agroforestry in GHG mitigation. In examining the agroforestry option, results from two other separate studies from

(IPCC, 2000c). This is offset by terrestrial uptake of carbon dioxide and results in a net terrestrial uptake of $0.2+1.0 \mathrm{Gt} \mathrm{C/} \mathrm{yr}$. 
Vietnam (UNEP, 1998) and Tanzania (Makundi and Okiting'ati, 1995) are also discussed. The paper illustrates the potential and costs of various mitigation options across countries, and provides some observations on how the analysis of mitigation potential and costs of forestry mitigation options could be improved to provide more realistic estimates of both.

The studies focus on quantifying the benefits of forestry practices, and generally do not identify policy changes or incentives necessary for their implementation. The potential barriers to implementation, and monitoring of carbon stock, raise complex issues with institutional, socioeconomic, public policy, gender role, and economic ramifications that would need to be addressed in order for these technically feasible options to be realized. The specific coverage of agroforestry sheds some light on a group of mitigation activities, which may find extensive applicability in developing countries.

\section{Analytical Approach}

The questions brought forth here require the use of a consistent analytical framework; a comprehensive mitigation assessment utilizing a consistent analytical framework is required. The COMAP model (Sathaye et al, 1995b), which was used in the studies summarized in this paper, has been extensively used in mitigation assessments by developing countries (see for example the US Country Studies Program). The approach requires the projection of land-use scenarios for both a baseline and for a mitigation case. In parallel, it requires data on a per hectare basis on carbon sequestration in vegetation, detritus, forest products, soils and also on GHG emission avoidance activities. In order to estimate the net monetary benefit per hectare or per $\mathrm{C}$, the model requires data on costs and benefits associated with all mitigation activities under consideration. These estimates are then combined with the land use scenarios in order to estimate cumulative or annual carbon flows and monetary costs and benefit over a specified future period, thus giving an estimate of potential and cost of mitigation activities in LULUCF for each country.

\subsection{MITIGATION OPTIONS AND THEIR CHARACTERIZATION}

The first step in mitigation assessment involves the characterization of mitigation activities which typically includes information on the carbon stored in various pools, their biomass growth and decay rates, the fate of the biomass, and the option's costs and benefits. In LULUCF there are three main types of mitigation activities - emission reduction, sequestration and substitution. Each GHG sub-sector in LULUCF has some or all of these mitigation opportunities. 
In agriculture, the emission reduction and substitution opportunities exist in rice cultivation, animal husbandry, biogas use for energy, fertilizer application and cultivation methods while offering carbon sequestration in agricultural tree crops, soil carbon storage and agroforestry. In rangelands and grasslands, emission reduction opportunities arise from improved range and fire management and improved animal husbandry while biomass replenishment and enhanced carbon storage in soils increase carbon sequestration. Emission reduction in waste management from land use mostly involves the use of animal and farm waste for biogas production for community energy needs.

The forestry sub-sector has more extensive mitigation activities, including forest conservation and protection, efficiency improvements and also substitution of fossil fuels and other products carbon intensive in the area of emission reduction and substitution. Forestry also sequesters carbon through increased vegetation cover (forestation), increased carbon storage in soils, and conversion of biomass to long-term products. Agroforestry combines both sequestration and emission reduction depending on the use of the wood products from the activity and the complementary effect on forest protection through avoided deforestation and unsustainable use of forest resources. Table 2 shows the list of specific mitigation options analyzed in this study. These options were not exhaustive, but rather those which the researchers believed had a high likelihood of being implemented and could be analyzed with the data and resources at hand.

\subsubsection{Comparison of parameters for the mitigation options}

The mean anmual increment MAI refers to the average rate of biomass growth over the life of a forestation option and they vary depending on species, site productivity and management regime. The MAI for the regeneration options varied from as low as $0.8 \mathrm{t} \mathrm{C/} \mathrm{ha/} \mathrm{yr}$ in China to about $3 \mathrm{t} \mathrm{C/} \mathrm{ha/} \mathrm{yr}$ in the Philippines, and for long-rotation plantations from $1.6 \mathrm{t} \mathrm{C/} \mathrm{ha/} \mathrm{yr}$ in China to as high as $11.1 \mathrm{t}$ $\mathrm{C} / \mathrm{ha} / \mathrm{yr}$ in Tanzania. The short-rotation plantations have higher rates ranging from $3.8 \mathrm{t} \mathrm{C} / \mathrm{ha} / \mathrm{yr}$ in China to $19.2 \mathrm{t} \mathrm{C/} \mathrm{ha/} \mathrm{yr} \mathrm{in} \mathrm{Tanzania.} \mathrm{To} \mathrm{the} \mathrm{extent} \mathrm{that} \mathrm{data} \mathrm{permitted,} \mathrm{each} \mathrm{study} \mathrm{accounted} \mathrm{for} \mathrm{the}$ increase in soil carbon, which was estimated to range from $0.5 \mathrm{t} \mathrm{C} / \mathrm{ha} / \mathrm{yr}$ in China to $3 \mathrm{t} \mathrm{C/} \mathrm{ha/} \mathrm{yr}$ in India.

Among the various forestation options studied, the rotation period varies from as short as 7-8 years for short-rotation planting in Mexico and India to as much as 50 years in the case of restoration plantations in Mexico. Generally the long-rotation plantations have periods ranging between 25-40 years. Regeneration options in each country have much longer periods to maturity, lasting as high as 80 years in northeastern China. 
The cost of planting is relatively uniform and stable over time and reflects the overall income levels in the country. Costs tend to be higher in Mexico (about $\$ 400-500 /$ ha), and lower in India, the Philippines, China and Tanzania (between \$150-300/ ha). Costs are higher for long-rotation plantations in each country. The life-cycle costs of these options, excluding harvesting, are only somewhat higher since the annual recurring cost of plantations tend to be small relative to the initial cost. The recurring costs include the cost of monitoring of carbon stocks.

In Indonesia, due to three- to four-fold drop in the value of the Indonesian currency (the Rupiah) since 1997, current costs in US dollars are significantly lower. Initial establishment costs range between $\$ 18$ / ha for enhanced natural regeneration to about $\$ 50$ / ha for a short-rotation plantation. However, once the devaluation effects nun through the monetary, factor and product markets, the long-term cost structure may well return. ${ }^{3}$

The costs of forest protectioni/conservation (excluding opportunity costs) and management options tend to be lower than those for forestation. Forest protection costs range from as low as $\$ 5$ / ha in the Philippines based on government budgets to as high as $\$ 41 /$ ha in southeast China. Experience in the countries shows that the lower values are clearly inadequate to accomplish conservation goals, and after factoring in the opportunity cost of land and labor, costs in every study country exceed the monetary benefits of forest protection/conservation.

Agroforestry options have investment costs varying from negligible in Tanzania where the opportunity cost of rural labour is miniscule, to medium cost in China at $\$ 80-\$ 140$ per ha and as high as $\$ 273$ per ha in Mexico. The cost of establishing and carrying out agroforestry activities can be elevated mostly due to the cost of the agricultural inputs.

\section{Land-use Context: Historical Trends and Future Scenarios}

Mitigation activities in the LULUCF compete for land in a zero-sum game. Land which is protected is essentially withdrawn from other potential uses, some of which may have different mitigation potential and cost. Forestation options face the staunchest competition for land due to the inherent need to reserve the most fertile land for agricultural production. Many factors drive the land use distribution in a country, including demographic variables (population growth rate, rural/urban population ratios); economic factors (incomes, export of primary products, growth

\footnotetext{
${ }^{3}$ For example, examination of data from Tanzania where the currency was systematically devalued thirty-fold between 1986 and 2000, (from 27 to 800 Shillings/ US dollar), shows the establishment cost for a forest plantation in the same locality (Sao Hill) changed from US \$217 to US \$200/ha (Makundi, 2001). The price of forest products shows similar stability over the period. This would tend to support the use of a pre-devaluation cost structure, since the current costs and prices are transitional and may be more reflective of the short-term shock associated with massive currency devaluation, than the underlying cost structure of a plantation program which is a long-term activity.
} 
rate); biophysical factors (climate, soil fertility); and land use intensity (shifting versus permanent agriculture, selective cutting versus clear cutting). Agroforestry relieves the pressure on natural forests somewhat given its ability to combine both wood and agricultural production on the same parcel of land.

\subsection{HISTORICAL LAND-USE PATTERNS}

The study countries constitute a very large land area of the world. Individually, the land area ranges from over 963 million ha for China, closely followed by Brazil's 845 million ha, to 30 million ha for the Philippines (Table 4). The forested area varies considerably, with Indonesia having as high as $57 \%$ of the land area in forests, followed by Brazil and Tanzania with $46 \%$ each. China has the lowest proportion (11\%) of the land area under forest cover.

The India, Indonesia, Mexico, and Philippines studies focussed on the entire forested area in each country, while the other countries covered only a portion of the forested area which were likely going to have the activities implemented. The Brazil study covered forestation in the Amazon region, while China study focussed on the three most forested regions out of five in the country, the northeast, southeast and southwest. The Tanzania study focuses on the miombo woodlands, which constitute about $95 \%$ of the forested area in the country and accounted for about $90 \%$ of the annual deforestation (Makundi and Okiting'ati, 2002).

The rate of deforestation is a highly complex and contested figure in any country, and thus difficult to compare across countries. The magnitude of deforestation is substantial even in countries where forest resources are not abundant. For example, the rate of deforestation for Indonesia has been reported to range from 0.75 to 1.5 million ha per year in the $1995-97$ period (Table 4)

(MOF, 1996, Walton and Holmes, 2000). The rate for Brazil has fluctuated from 1.1 to $2.9 \mathrm{M}$ ha from the late 1980 s to early 1990s (www.mct.br/clina/ingles/communic old/amazinpe.htm)??? The estimate of deforestation for Tanzania and Mexico is about 0.750 and 0.720 million ha per year respectively, though the official figures claim a lower rate in both countries (Makundi and Okiting'ati, 2002; Masera et al, 1997). Slowing deforestation would clearly reduce emissions but implementing options and enforcing policies to achieve this is often thwarted by, among other factors; the high opportunity cost of land and the lack of comparable alternative opportunities to earn a living in rural areas.

Is there enough land available for climate mitigation activities in the developing countries? At first glance, the prohibitively high population densities and low agricultural productivity in some of the study countries might seem too restrictive to allow land to be used for forestation. As Table 3 
indicates, however, estimates of degraded lands or wasteland available for forestation, (without considering economic, social, cultural, and other barriers), amount to several tens of millions of hectares. For comparison, Table 3 also shows the potential estimated by Trexler and Haugen, (1995) for regeneration, farm forestry (agroforestry) and plantation options for the period 1990 to 2040. This land either originally contained forests or has been left fallow and agriculture is no longer practiced for various social and economic reasons. Much of this land is suitable or could be made suitable for forestation programs in the study countries. This may require a change of management from individual farmers to that by private companies and commensurate harvesting, or include incentives to individual farmers to re-orient their land use practices. China and India both import wood products with a value of several hundreds of millions of dollars (Adenoid and Ravindranath, 1995; Zhang et. al., 2000), and forestation programs on such lands could offset at least part of this drain on their foreign exchange reserves, while simultaneously providing rural socioeconomic benefits if the programs were sustainably managed.

\subsection{FUTURE LAND-USE SCENARIOS}

A baseline scenario, and one or two alternative mitigation scenarios were constructed for each study country for the period 2000-2030. The baseline scenario represents a set of assumptions about likely changes in land-use and land-cover patterns in the country based on historical data and emerging demographic and economic trends. In the mitigation scenarios, activities such as afforestation or forest protection are explicitly identified, and simulated using the COMAP model in order to estimate the change in the number of hectares and associated carbon stock for each type of land use throughout the period under consideration, as well as costs and selected benefits. In general, this simulation is based on projected demand for forest products, with the mitigation scenario examining an alternative to produce the products at lower GHG emissions implication or at an increased carbon sequestration level.

Several of the countries have ambitious govemment plans which were intended to meet the countries needs for forest products and services (Table 4). Invariably, these plans been only partially implemented because of lack of resources, economic and policy incentives, and social reasons. In these cases, the mitigation scenario studied here used the forestry sector targets set forth in the govemment plans as the basis for setting the mitigation level. The analysts based their estimate of the level on the past history of implementation success of similar previous plans. Table 5 below shows the land-use scenarios that form the basis for the mitigation scenarios presented in this summary paper. The scenarios are described below: 
Brazil: One mitigation scenario was analyzed in a preliminary analysis using the COMAP model. This limited scenario is based on land use projections from Trexler and Haugen, 1995, for regeneration and plantation activities only; other options like avoided deforestation or forest management are not included since corresponding cost data were not readily available to the authors. The baseline scenario assumes that future land would have remained in its current state. We focus on two selected activities among many others that could be implemented. The total land area under mitigation amounts to 19.8 Mha by 2030 .

China: Two altemative scenarios were analyzed. One scenario reflects government plans which call for forest area to be increased by 27.3 Mha from 1999 to 2010 and by another 46 Mha from 2011 to 2030, and 18.9 Mha and 35Mha of new nature reserves would be established during the respective periods. In addition, $13 \mathrm{Mha}$ are planned to be established between 1999 to 2010 under agroforestry. Table 5 shows a second more conservative scenario that would achieve $60 \%$ of the goal of the government plan. The land available for regeneration is an order of magnitude higher than that for short- and long-rotation plantations by 2030, and a small amount of land is slated to be added to areas already under protection.

India: Two alternatives, a sustainable forestry scenario, which is shown in Table 5, and a commercial forestry scenario were evaluated. The first one is designed to meet the incremental national biomass demand between 2000 and 2015, and includes increased forest protection and regeneration options. The second one focuses on meeting the increased biomass demand primarily through commercial forestry. The wasteland available for forestation is quite large, almost $30 \mathrm{Mha}$, and the amount of land which could benefit from additional protection is 8.5 Mha.

Indonesia: Two alternative scenarios, a government-plans scenario and a mitigation scenario, were analyzed. The first scenario projects forestation rates similar to those in the government plan as laid out in Repelita VI (1998-2003), although historically these have been rarely achieved. The mitigation scenario assumes that the rate of timber plantation establishment is increased such as to meet all wood demand by 2010 (Table 4). Short-rotation plantations, enhanced natural regeneration, long-rotation reforestation, and reduced impact logging options dominate the 29.2 Mha of land available for forestation activities.

Philippines: As in the case of Indonesia, the government's forestry master plan scenario and a mitigation scenario are analyzed. The master plan assumes aggressive tree planting to meet local demand for wood products. The second scenario assumes a forestation rate, which is $50 \%$ of the govermment plan scenario (Table 4). The total land area available for mitigation in this scenario is 
relatively small, about 1.7 Mha by 2030; much of this is concentrated in short- and long-rotation plantations. Another 0.1 Mha is identified for protection.

Mexico: One alternative mitigation scenario is analyzed, which assumes improved penetration of all mitigation activities. In this scenario, 2030 deforestation rates will have been reduced to $25 \%$ of current ones, native forests are managed more efficiently with improved survival rates, plantations make Mexico self-sufficient in paper and cellulose products, and bioenergy plantations play a prominent role (Table 4). Restoration plantations, i.e., plantations established to restore degraded land, and management of temperate forests constitute the bulk of the land requirements for mitigation activities. By 2030, a total area of 9.1 Mha would be under some form of mitigation activity in this scenario.

Tanzania: The main mitigation scenario analyzed involves implementation of the Tropical Forest Action Plan (TFAP) for establishing community short rotation woodlots to meet $50 \%$ of the demand for wood fuel, sawlogs and chiplogs. Two versions of this scenario are analyzed. The first scenario which is reported here involves the conversion of 1.7 Mha of woodlands to short rotation plantations terminating in 2024, assuming that the demand for these products will have peaked, and the plantations are managed in perpetual rotations (Table 4). Other less extensive afforestation scenarios for long rotation industrial softwood and hardwood were also analyzed.

\section{Summary of results}

\subsection{CARBON STOCK SCENARIOS ${ }^{4}$}

The vegetation carbon stock in the study countries varies with the largest stock in Brazil, followed by Mexico, Indonesia, China, India, Tanzania, and the Philippines. The land-use and land-cover change scenarios lead to significant opportunities for improving the biomass and carbon pools in the future, that increase with the time period of study.

Table 5 shows the changes in the live vegetation carbon stock under the two scenarios. Except in China, the total carbon stock declines between 1990 and 2030 in the baseline scenario as deforestation is anticipated to continue into the future. Slowing deforestation thus constitutes an important opportunity to reduce or avoid emissions. By 2012, the difference in carbon stock varies between $53 \mathrm{Mt} \mathrm{C}$ in Tanzania to $728 \mathrm{Mt} \mathrm{C}$ in India. The India figure is deceptively high because a large part of the forest is assumed to need protection. The cumulative potential by 2012 compared to 2000 amounts to $1807 \mathrm{Mt} \mathrm{C}$ which increases to $6155 \mathrm{Mt} \mathrm{C}$ by 2030 . On an annual average basis, the 
potential for the seven countries amounts to about $125 \mathrm{Mt} \mathrm{C}$ / yr between 2000 and 2012, and $218 \mathrm{Mt}$ C / yr between 2013 and 2030 .

This study estimates the cumulative potential in Brazil for short- and long-rotation plantations to be $87 \mathrm{Mt} \mathrm{C}$ by 2012 increasing to $448 \mathrm{Mt} \mathrm{C}$ by 2030, but it did not evaluate the potential for avoidance of emissions from deforestation. A recent report (Da Motta, et. al. 1999) suggests that this potential is of the order of $2718 \mathrm{Mt} \mathrm{C}$ and that for natural forest management amounts to another $735 \mathrm{Mt} \mathrm{C}$. Combined with the estimate in this study, the total cumulative potential in Brazil for the four options would add up to about $3900 \mathrm{Mt} \mathrm{C}$. or almost $70 \%$ of the cumulative amount estimated for all other study countries combined.

Table 5 below shows the cumulative carbon potential and the associated cost of the mitigation scenario assessed from the year 2000 to the end of the first Kyoto Protocol commitment period (2012), and also for 2000 to 2030 . The cost estimate indicates the value of resources needed to implement a mitigation scenario without regard to its monetary benefits or cost of baseline forestry activities. Thus these estimates overstate the likely actual net cost of these mitigation options, and do not address who would pay these costs and receive monetary benefits form timber harvest or other revenues - a combination of public and private entities. Note that the cumulative cost in 2000-2012 is more than half of that for 2000-2030, mostly due to the effect of discounting on the skewed profile of costs and benefits of forest mitigation.

Except for India, the cost figures include the opportunity cost of land for the forest protection option. Other costs for the baseline scenario are not deducted. These projected costs may be compared with historical data for the amount of money allocated from the government budget to the forestry sector in each country. The government budget varies in each country, but in all cases it represents a fraction of the cost reported in Table 5 for a carbon mitigation scenario.

\subsection{ECONOMIC IMPLICATIONS OF THE POTENTIAL}

The activities noted in Table 2 form the basis for the mitigation carbon scenarios shown in Table 5. In this section, we focus on two topics, (1) cost-effectiveness of mitigation options and the potential for carbon sequestration and emissions avoidance, and (2) present value of the cumulative costs of mitigation scenarios. The latter information is useful for potential investors and government policy makers in assessing the investment needed for a regional or national scenario that contains a mix of mitigation options.

\footnotetext{
4 The COMAP model version 3 computes the equilibrium carbon stock in live and decomposing vegetation, soils and products. It also computes the annual live vegetation carbon stock from 1990 to 2030 . We report on the changes in the
} 
Much of the economic analysis of climate change mitigation options in the forestry and other sectors has focused on the estimation of the cost effectiveness (costs or net benefits per $t \mathrm{C}$ ) of options (Brown et al., 1996 and IPCC, 2001c). This estimation permits a ranking of options by their costs or net benefits, which provides policy makers with information about the comparative importance of each option.

\subsubsection{Cost effectiveness of mitigation options}

The cost effectiveness indicator of mitigation activities i.e., an option's cost per $t C$. depends on the extent to which all factors contributing to net costs and changes in carbon stock have been included, and the time period over which these are measured. The reporting of costs of LULUCF mitigation options has largely been limited to the estimation of investment or establishment cost per ha or per $t$ C (Brown et al. 1996, and Sathaye et al., 2001). The IPCC Report (IPCC, 2001a op. cit.) provides additional infomation on the net present value (NPV) per $t C$ for selected forestry options in developing countries. An estimate of the establishment cost and NPV per t C for Brazil, India, China, Malaysia, Mexico, Tanzania, and Thailand was published in 1995 (Sathaye and Makundi, 1995). The data and information reported in this set of studies expands that approach to the estimation of costs by reporting the anmualized cost per $\mathrm{t} C$ for a specified period, and the mitigation carbon potential relative to a baseline scenario.

For estimating cost effectiveness of options the approach used here involves accounting for all the cost elements and non-carbon benefits of an option, annualize these for a specified period (20002030), and then express the net costs in terms of the average annual carbon emissions avoided or carbon sequestered, i.e., the annualized net cost (benefit) per t $\mathrm{C}$ (henceforth referred to as cost per $\mathrm{t}$ C). We report this parameter for the mitigation option after deducting the cost per $\mathrm{t} C$ estimated for the baseline scenario. The latter represents the foregone opportunity cost of the baseline option. This approach to estimating the cost is comparable to that described by UNEP for energy projects (UNEP, 1998). The estimated value may be compared with a potential international price of carbon, or the cost per $\mathrm{t} C$ for mitigation activities in other sectors such as energy, industry and waste management.

An important caveat is worth noting in using this approach. Carbon flows of forestry projects unlike those from energy projects vary over time. An energy mitigation project is assumed to provide constant annual emissions reductions, but the amount of carbon sequestered in a forestry project varies annually and reaches equilibrium after a species reaches maturity or is harvested within a sustained yield management regime (Sathaye et al, 1995a). Also, the cost and benefits for non-carbon

annual stock in this section. 
inputs and outputs come at different times, with most of the costs being incurred at the beginning of the project while benefits e.g. timber are realized at the end of rotation period. Averaging annual carbon flows over a defined time period is thus an artifact that permits the cost per $\mathrm{t} C$ for forestry projects to be compared with that for energy projects.

The cost per $t \mathrm{C}$ was estimated for each country in the study for the options listed in Table 2 . The cost per $\mathrm{t} C$ was matched with the cumulative vegetation carbon (above and below ground) sequestered or emissions avoided between 2000 and 2030 .

A discount rate of $10 \%$ real (after accounting for inflation) is used for China, Indonesia, Mexico, Tanzania and Brazil, and 12\% real for India and the Philippines. These rates reflect the rates used by multilateral banks to evaluate energy and forestry projects in the study countries. Private discount rates are likely to be much higher, e.g., approaching 18\% real in Brazil (Meyers et al. 2001). On the other hand, for environmental projects a rate of $6 \%$ has been suggested by the Indian Planning Commission (Kadekodi and Ravindranath, 1995). There is a significant school of thought in the literature which generally advocate the use of lower discount rates in evaluating long term, environmental and social programs or projects than those used for short term, commercial or private projects (Sathaye and Makundi, 1998).

A negative cost indicates that the direct revenue generated by the mitigation option from the sale of timber and other products exceeds its costs, including the price or opportunity cost of land. The carbon potential at a negative cost per $\mathrm{t} C$ varies across countries. This potential depends on the options selected for study in each country, the magnitude and time profile of the baseline and mitigation carbon, its costs, and the prices and yields of timber and non-timber products. The time profile of the above monetary and carbon factors has a significant impact on the estimated costs because of the aforementioned high discount rates.

In China, because of the high price that timber and non-timber products are assumed to fetch relative to costs, all nine options (three different ones in each of the three study regions) are estimated to have a negative cost per $\mathrm{t}$, and for similar reasons, the costs are negative for Brazil. On the other hand for India, cost per t C is negative only for the regeneration option largely because its cost of planting is very small. Short-rotation plantations and regeneration offer negative cost opportunities in the Philippines. Short-rotations plantations also have negative costs in Mexico, Indonesia and Tanzania. In Mexico, long-rotation plantations, forest management and bioenergy are estimated to be negative cost options too. All other options are estimated to have positive costs. Forest protection is the 
highest cost option in three countries the three countries that evaluated this option (India, the Philippines and Indonesia), mostly due to the high opportunity cost.

\subsubsection{The Mitigation Supply Curve}

Figure 1 shows a step curve representing the potential supply schedule for carbon in forestry mitigation activities in the seven studied countries. Each segment represents an amount of carbon which can be sequestered or protected at a specific net discounted cost between 2000 and 2030 .

The larger countries dominate the combined potential for carbon sequestration. The combined cost curve for all options across the study countries shows that about half the cumulative carbon potential may be realized at a negative cost, which is about $150 \mathrm{M} \mathrm{tC}$ per year which can be sequestered or protected at a net non-carbon benefit over 30 year period. Coincidentally, this finding is sinilar to that reported for the energy sector in the TAR (IPCC, 2001c). The IPCC Third Assessment Report (Metz and Davidson, 2001) shows that about half the technology potential worldwide could be tapped at a negative cost and the other half at a cost ranging up to $\$ 100$ per t C. The positive cost potential may be seen as the minimum carbon price that would be needed to implement these options, without counting the benefits associated with the reduction of atmospheric carbon. Under a carbon price of say $\$ 20$ per t C, the cumulative potential between 2000 and 2030 amounts to about 5 Gt C. Though the mitigation curve depicted below is dominated by conventional forestation and protection activities, a two countries, China and Mexico included some agroforestry options in their assessment. However, this option has a potential for much broader role in carbon sequestration and emission reduction given the extensive likely application in the rural and farm economies.

\section{Role of Agroforestry}

In general, agroforestry involves growing or managing tree crops with agricultural crops. The term is also used to include silvi-pastoral activities that involve growing or management of tree crops in the same land area with a significant practice of animal husbandry. Wood from agroforestry projects involving harvesting can also be utilized in such a way that the emission reduction is enhanced compared to the reference scenario. Such uses may include:

(i) more efficient charcoal production (kilns), packaging (briquettes), utilization (cook stoves), improved use of charcoal for industry (e.g. steel, tobacco and tea curing) etc.

(ii) use of the sustainably grown biomass to replace fuel wood from depletable natural forests, 
(iii) use of sustainably-grown biomass for fossil fuel substitution, including, woodfuel, ethanol and bio-electricity as well as substituting high emission content products e.g. cement and steel with wood from agroforestry.

There are a variety of agroforestry practices, which have been in existence in different countries.

Such practices which may be expanded for the benefit of GHG mitigation include but not limited to:

- inter-cropping for the purpose of producing both agricultural and forest products

- boundary and contour planting for demarcation and protection against wind and soil erosion as well as agricultural and wood products

- shifting cultivation which is followed by succession vegetation, with or without fallow

- taungya system (inter-cropping in the forest before canopy closure) applied as an integral part of forest management, in both natural and plantation forestry

- pastro-silviculture for producing both forest and animal husbandry products from the same management unit,

- non-timber tree farms such as those established for rubber, tamins, bamboos, rattan, are in many cases considered under agro-forestry since they are seldom included in plantation forestry

- Orchards and woody fruit trees may also be classified under agroforestryt

\subsection{METHODOGICAL STEPS FOR ASSESSING AGROFORESTY FOR GHG MITIGATION}

(i) Identification and description of types of applicable agroforestry activities with potential for carbon sequestration or emission reduction compared to a reference case. For each type of activity to be analyzed, a baseline has to be described. In some cases the baseline is shifting cultivation, in other cases it is farming of permanent annual crops, though in some cases farming of perennials (or sparse tree crops) can also be improved by increasing the woody biomass density.

(ii) Assessment of the current and future land area available for agroforestry. Large agricultural areas may not be amenable to significant inter-cropping due to crop husbandry requirements e.g. shade intolerant crops, mechanized farming, etc.

(iii) Assessment of the current and future product demand from the agroforestry activities help in the determination of the land area and wood production scenarios under each agroforestry activity. The wood products from these activities will be supplemental to the supply from the country's forest estate. In many cases the trees will be harvested at maturity, and the demand for the agricultural crop and wood product will drive the extent of carbon sequestration via such activities. However, in some cases e.g. shade trees and 
shelterbelts, the trees may not be harvested at maturity. In this case the estimate for the area which will be put under agroforestry is determined strictly by the demand for the required service, e.g. shade trees, wind breaks, demarcation, etc.

(iv) Estimate the GHG impact per hectare for each agroforestry activity. The carbon accounting for agroforestry is essentially based on individual tree measurements, which can then be used to generate allometric equations for wider area application. If the trees are not for periodic harvesting, the carbon sequestration will be estimated on the basis of maximum growth to maturity, possibly including any emission reduction from avoided erosion. This is equivalent to plant and store approach (Makundi, 1995). If the tree crop will be harvested at maturity, usually the planting is staggered so as to ensure a stable tree cover through harvesting only a small proportion of the tree crop - ideally a rotation-th of the crop annually or periodically. This is equivalent to carbon accounting for perpetual rotations (Makundi, 1995 op cit).

(v) Estimate unit costs and benefits for each mitigation activity. The direct costs and benefits should only involve the tree crops, though we may consider indirect impacts if they are compelling. For example, the intercropping of nitrogen-fixing leguminous tree species e.g. leucaena leucocephala or acacia spp. increases the productivity of the agricultural crop. This increase may need to be estimated and counted in the incremental benefit column. The opportunity cost of the land may not be an issue if the reference case involves conventional agricultural activities. The non-market and intangible costs and benefits should be imputed

if possible, otherwise they should be itemized and described for the purpose of supplemental criteria for ranking different mitigation options.

(vi) Using the estimates of GHG impact and cost and benefits, compute the cost-effectiveness indicators per unit area and per t C e.g. present value of cost, net present value (NPV), initial cost, etc.

\subsection{CONTRIBUTION OF AGROFORESTRY}

As indicated above, only China and Mexico evaluated Agroforestry among the study countries. However, Vietnam had undertaken a mitigation assessment under a separate study (UNEP, 1998) in which agroforestry was evaluated. Similarly, in a different study for Tanzania, three types of agroforestry activities were evaluated (Makundi and Okiting'ati, 1995) and their cost effectiveness estimated. Both these studies used the same methodological approach (COMAP) which was applied used in the seven studies reported in this paper. In discussing the role of agroforestry for 
mitigation assessment, results from these earlier studies will also be discussed together with those of China and Mexico.

In the three regions in China which were studied and reported above, $42 \%$ of the 78 million hectares of land available for mitigation activities is classified as suitable for agroforestry (Table 6). In the mitigation scenario analyzed, 19.5 million hectares of this available land was put under agroforestry (Table 7). However, due to the low carbon density of agroforestry systems ( $46.5 \mathrm{t} \mathrm{C/}$ ha), of the $2093 \mathrm{M} \mathrm{tC}$ which will accumulate in the mitigation scenario, only about $292 \mathrm{M} \mathrm{t} \mathrm{C}$ will be in agroforestry - which is 14 percent of the potential in Chinese LULUCF sector.

In the China study, since the benefits from the agricultural crop was not considered, an estimate of NPV would be misleading when compared to the other options, and as such we made no effort to the individual cost and benefit items for the agroforestry option. The total investment cost is presented for this option was comparatively low, ranging between $\$ 80-140$ per ha with a weighted average of $\$ 108$ per ha. (Table 7 ), compared to the other options which had an investment ranging from $\$ 280-\$ 11420$ per ha. The range is wide due to the high investment cost in bioenergy programs. The low investment per unit in agroforestry can be attributed to the dispersed nural nature of agroforestry and utilization of cheap farm labour on land which was of low opportunity cost.

Mexico's analysis of change in the carbon stock showed large increases in emissions from deforestation in the unmanaged temperate coniferous and degraded forestlands, but had a substantial gain in the tropical and temperate hardwood forests. Agroforestry shows a cumulative sequestration of $255 \mathrm{Mt} \mathrm{C}$ by 2030 , about $20 \%$ of all mitigation potential in the LULUCF in Mexico. This is comparable to the annual agroforestry potential for China which was estimated at $10 \mathrm{Mt} \mathrm{C}$.

Table 9 shows the costs for selected mitigation options, with agroforestry having a relatively low investment cost estimated at $\$ 173 /$ ha or $\$ 273 /$ ha life cycle cost. The only lower cost option was temperate forest management at $\$ 94 /$ ha life cycle cost. The cost per unit for agroforestry is also low $(\$ 4-\$ 10 / \mathrm{t} \mathrm{C})$ despite a low sequestration carbon density $(27-66 \mathrm{t} \mathrm{C} / \mathrm{ha})$. The reasons for the low cost are similar to those for other countries, specifically low cost of inputs like labour in rural areas. The exclusion of the value of the agricultural produce also makes the NPV non-comparable to the other options and was not reported. 
Two other studies for which this framework has been applied (Vietnam and Tanzania) produced

similar results to those reported here in terms of relative cost and potential. In a 1998 UNEP study on mitigation analysis for Vietnam, one of the options studied would involve planting scattered trees in and around farms in the countryside. The results showed an estimated potential to sequester about $48 \mathrm{t} \mathrm{C/} \mathrm{ha} \mathrm{at} \mathrm{a} \mathrm{discounted} \mathrm{cost} \mathrm{of} \$ 59.2$ / ha, giving a discounted unit cost of $\$ 1.35$ /t C (Table 10). The total amount of carbon sequestered under agroforestry was estimated at 78.7

Mt C representing about 6 percent of the four mitigation options considered. The cost of implementing this option is much higher than that of protection and is comparable to enhanced natural regeneration, though it is about a third of the cost for a ton of Carbon sequestered under reforestation. The Protection option is relatively cheaper since it does not include opportunity cost of the protected forest area.

A different study which was done for Tanzania (Makundi and Okiting'ati, 1995) compared the cost effectiveness of three different agroforestry schemes and compared their cost effectiveness per t $C$ with two forestry options using different management regimes. The study showed that intercropping between short rotation tree species and com was the most cost effective with NPV ( $\$$ $4.67 / \mathrm{t} \mathrm{C}$ ). The longer rotation regimes having roughly the same low NPV (\$0.29/t C and $\$ 0.27 / \mathrm{t}$ C respectively) regardless of the whether they were using inter-cropping or boundary scheme (Table 11). However, the longer rotation agroforestry schemes had significantly more carbon sequestered compared to the short rotation. The two plantation forestry options had three times the carbon sequestration potential than agroforestry option using same rotation and species. The govemment run option was the least cost effective, with a negative NPV ( $\$-0.43 / \mathrm{t}$ ) compared to the community/government partnership which sequestered the same amount of carbon but with an NPV of $\$ 3.4$ per t $C$, second only to the short rotation agroforestry option.

Though there was no attempt to extrapolate these results for the whole country, the fact that $80 \%$ of the population is dependent on agriculture and most live in similar ecosystems (miombo woodlands) to the area where these options were implemented, would suggest a very large potential at a positive net present value. It is noteworthy that for the country, a mixture of these schemes would be necessary since the use of the wood products is species dependent, and different agricultural practices may require different agroforestry schemes. 


\section{Conclusions}

In this paper, we report a summary of results of carbon mitigation and associated costs and benefits in forestry from in some developing countries, with a specific emphasis on the relative role of agroforestry as a mitigation activity. The studies applied a common analytical framework to estimate the potential and produce cost effectiveness indicators for the purpose of comparing and ranking the options. The paper also reports on the estimated the cumulative amount of carbon which can be sequestered (or emissions avoided) by the first commitment period of the Kyoto Protocol (2000 - 2012), and for a longer period (2000 - 2030), as well as the costs and benefits of undertaking the activities. The paper then examines the relative role of agroforestry in the potential and costs in those countries where agroforestry activity was analyzed. To complement this assessment, the results of two other studies separately conducted in two developing countries using the same analytical framework are presented, with a focus on the agroforestry options.

The results show that about half the mitigation potential of $6.9 \mathrm{Gt} \mathrm{C}$ (an average of $223 \mathrm{Mt} \mathrm{C}$ per year) between 2000 and 2030 in the seven countries could be achieved at a negative cost, indicating that non-carbon revenue is sufficient to offset direct costs of about half options. The other half can be offset by a cost of less than $\$ 100$ per $\mathrm{C}$. The agroforestry options analyzed bear a significant proportion of the potential at medium to low cost per $\mathrm{C}$ when compared to other options. The role of agroforestry in these countries varied between 6 and 20 percent of the mitigation potential, though the options are much more cost effective due to the low wage or opportunity cost of rural labour. If the value of additional agricultural output caused by the application of agroforestry was included in the analysis, then the option would be more cost effective. Also, agroforestry options are attractive due to the large number of people engaged in agriculture and can be implemented at a very small practical scale. The potential and cost presented above face many barriers.

The main barriers are technical (skills and know how of managing tree crops and their products), financial (capital and credits) and institutional (different interests between farmers and forest departments and industry). These barriers would require targeted policies and incentives in order to smoothly implement the mitigation options. The forestry policies mostly require formulation and implementation of effective forest protection and conservation policies which will serve as incentives to agroforestry activities. Policies which impede slash-and-burn or shifting cultivation may encourage the adoption of sedentary agroforestry. Also, there has to be complementarity 
between the forest sector production and the agroforestry policies since individual farmers engaged in agroforestry may be unable to compete with the commercial production forestry, especially for wood products harvested from natural forests.

Another set of non-forest sector policies will also be essential in order to breach the gap between the technical and achievable potential. These include land tenure policies e.g. public versus private lands, agricultural and rural development policies which encourage agroforestry and promote the products, tax incentives and access to credit, trade policies to protect the output from agroforestry, including aggressive marketing for export, tariffs, etc However, agroforestry options pose unique challenges for carbon and cost accounting due to their dispersed nature and their dependence on the specific farm economy. Other important concems arise from the specific issues regarding monitoring, verification, leakage and the establishment of credible baselines.

\section{References:}

Asia Least-cost Greenhouse Gas Abatement Strategy (ALGAS): 1998, Final ALGAS Summary Report. Asian Development Bank, Manila.

Brazil, INPE (Instituto Nacional de Pesquisas Espaciais): 1998, Amazonia: Deforestation 1995 1997, INPE, São José dos Campos, SP, Brazil. Document released via internet (http://www.impe.br).

Brazil, INPE (Instituto Nacional de Pesquisas Espaciais): 1999, Monitoramento da Floresta Amazônica Brasileira por Satélite/Monitoring of the Brazilian Amazon Forest by Satellite: 1997-1998, INPE, São José dos Campos, São Paulo. Document released via internet (http://www.inpe.br).

Boer, R.: 2001, Economic Assessment of Mitigation Options for Enhancing and Maintaining Carbon Sink Capacity in Indonesia. Mitigation and Adaptation Strategies for Global Change, $6,313-334$

Brown, S., J. Sathaye, M. Cannell, and P. Kauppi:. 1996, 'Chapter 24: Management of Forests for Mitigation of Greenhouse Gas Emissions', in R. Watson, M. Zinyowera and R. Moss (eds) Climate Change 1995: Contribution of Working Group II to the Second Assessment Report of the Intergovernmental Panel on Climate Change, . Cambridge University Press, Cambridge U.K..

Da Motta S., C. Young, and C. Ferraz: 1999,. 'Clean Development Mechanism and Climate Change: Cost Effectiveness and Welfare Maximization in Brazil' Report to the World Resources Institute, Institute of Economics, Federal University of Rio de Janeiro, Brazil, pp. 42.

Feamside, Philip M.: 2001, 'The potential of Brazil's forest sector for mitigating global waming under the Kyoto Protocol', Mitigation and Adaptation Strategies for Global Change 6, 355-372 
Fearnside, P.M.: 1997b, 'Monitoring needs to transform Amazonian forest maintenance into a global warming mitigation option', Mitigation and Adaptation Strategies for Global Change 2(2-3), 285-302

Intergovernmental Panel on Climate Change (IPCC): 2000a. Chapter 3: Afforestation, Reforestation and Deforestation (ARD) Activities, in R. Watson, I. R. Noble, B. Bolin, N.H. Ravindranath, D.J. Verardo, D.J. Dokken. (eds) Land Use, Land-use Change, and Forestry. A Special Report of the IPCC, Cambridge University Press. Cambridge, UK, $377 \mathrm{pp}$.

Intergovernmental Panel on Climate Change (IPCC). 2000b. 'Chapter 3: Additional HumanInduced Activities - Article 3.4 ', in R.T. Watson, I. R. Noble, B. Bolin, N.H. Ravindranath, D.J. Verardo, D.J. Dokken. (eds) Land Use, Land-use Change, and Forestry. A Special Report of the IPCC, Cambridge University Press. Cambridge, UK, $377 \mathrm{pp}$.

Intergovernmental Panel on Climate Change (IPCC). 2000c). 'Summary for Policy Makers', in R.T. Watson, I. R. Noble, B. Bolin, N.H. Ravindranath, D.J. Verardo, D.J. Dokken. (eds) Land Use, Land-use Change, and Forestry. A Special Report of the IPCC, Cambridge University Press. Cambridge, UK,

Intergovernmental Panel on Climate Change (IPCC): 2001a, 'Chapter 4: Technological and Economic Potential of Options to Enhance, Maintain and Manage Biological Carbon Reservoirs and Geo-Engineering', in B. Metz, O. Davidson, R. Swart and J. Pan (eds): Contribution of Working Group III to the Third Assessment Report of the IPCC. Cambridge University Press, Cambridge, UK

Intergovernmental Panel on Climate Change (IPCC): 2001b, 'Chapter 5: Barriers, Opportunities, and Market Potential of Technologies and Practices', in B. Metz, O. Davidson, R. Swart and J. Pan (eds): Contribution of Working Group III to the Third Assessment Report of the IPCC. Cambridge University Press, Cambridge, UK.

Intergovernmental Panel on Climate Change (IPCC): 2001c, 'Chapter 3: Technological and Economic Potential of Greenhouse Gas Emissions Reduction', in B. Metz, O. Davidson, R. Swart and J. Pan (eds): Contribution of Working Group III to the Third Assessment Report of the IPCC. Cambridge University Press, Cambridge, Cambridge, UK..

Kadekodi, G.K. and N.H. Ravindranath: 1995, 'Macro-economic Analysis of Forestry Options on Carbon Sequestration in India'. Working Paper E/173/95, Institute of Economic Growth, Delhi University Enclave, Delhi.

Lasco, R.D. and Pulhin, F.B.: 2001. Climate Change Mitigation Activities in the Philippine Forestry Sector: Application of the COMAP Model. Mitigation and Adaptation Strategies for Global Change, 6, 313-334.

Makundi, W.: 1995, 'Chapter 11: Forestry', In: J. Sathaye and S. Meyers (eds): Greenhouse Gas Mitigation Assessment: A Guidebook. Kluwer Academic Publishers. Dordrecht, Netherlands

Makundi, W.R.: 2001 - Greenhouse Gas Mitigation Potential in the Tanzanian Forest Sector. Mitigation and Adaptation Strategies for Global Change. 6, 335-353 
Makundi W.R. and Okiting'ati, A.: 1995, 'Carbon Flows and Economic Evaluation of Mitigation Options in Tanzania's Forest Sector' Biomass and Bioenergy 8, 381-393

Makundi, W.R. and Okiting'ati, A.: 2002. Greenhouse Gas Emissions and Carbon Sequestration in the Forest Sector of Tanzania. Submitted to: Climatic Change.

Masera, O.R., Ceron A.D. and Ordonez, A.: 2001, Forestry Mitigation Options for Mexico: Finding Synergies Between National Sustainable Development Priorities and Global Concerns. Mitigation and Adaptation Strategies for Global Change,6, 291-312

Masera, O.R., Ordonez, M.J. and Dirzo, R.: 1997. Carbon Emissions from Mexican Forests:

Current Situation and long-term Scenarios. In: Climatic Change 35. 265-295

Ministry of Forestry (MOF): 1996, 'Forestry Statistics of Indonesia 1994/95' Agency for Forest Inventory and Land Use Planning, Ministry of Forestry, Jakarta, Indonesia.

Metz, B. and Davidson, O. (eds): 2001, 'Mitigation-- Working Group III Contribution to the Intergovernmental Panel on Climate Change (IPCC)', Third Assessment Report, Cambridge University Press.

Meyers, S., Sathaye, J., Lehman, B., Schumacher, K., van Vliet, O. and Moreira, J.: 2001, 'Preliminary Assessment of Potential CDM Early Start Projects in Brazil' LBNL Report 46120, Berkeley, USA

Ravindranath, N.H., Sundha, P. and Sandhya, R.: 2001, Forestry for Sustainable Biomass Production and Carbon Sequestration in India. Mitigation and Adaptation Strategies for Global Change, 6, 233-256

Sathaye, J. and Ravindranath, N.H.: 1998, 'Climate Change Mitigation in the Energy and Forestry Sectors of Developing Countries', Annual Review of Energy and Environment 23, 387-437.

Sathaye, J., Meyers, S., Allen-Diaz, B., Cirillo, R., Gibbs, M., Hillsman, E., Makundi, W. and Ohi, J.: 1995a, Greenhouse Gas Mitigation Assessment: A Guidebook, Kluwer Academic Publishers, Dordrecht, Netherlands.

Sathaye, J.A. and Makundi, W.R.. (Eds). 1995. Forestry and Climate Change. Special Issue: Biomass and Bioenergy 8, 279-393.

Sathaye, J.A. and Makundi, W.R.: 1998. 'Chapter 7 -- Long-term and Cross-sectoral Cost Issues', in Mitigation and Adaptation Cost Assessment - Concepts, Methods and Appropriate Use. UNEPUCCEE, Roskilde, Denmark.

Sathaye, J.A., Makundi, W.R. and Andrasko, K.E.: 1995b. 'A Comprehensive Mitigation Assessment Process (COMAP) for the Evaluation of Forestry Mitigation Options' Biomass and Bioenergy8, 345-356

Trexler, M. and Haugen, C.: 1995. Keeping it Green: Evaluating Tropical Forestry Strategies to Mitigate Global Warming. World Resources Institute, Washington, D.C. 
UNEP, 1998. Mitigation and Adaptation Cost Assessment - Concepts, Methods and Appropriate Use. UNEP-UCCEE, Roskilde, Denmark

UNEP, 1998.'Asia Least Cost Greenhouse Gas Abatement Strategy- ALGAS Vietnam Final Report', $A D B / G E F-U N D P$ project, Asia Development Bank, Manila .

Walton, T. and Holmes, D.: 2000, 'Indonesia's Forests are Vanishing Faster than Ever' International Herald Tribune, January 25, 2000.

Xu, D., Zhang, X.Q. and Shi, Z.: 2001. Mitigation Potential for Carbon Sequestration and Emission Reduction through Forestry Activities in Southern and Eastern China. Mitigation and Adaptation Strategies for Global Change, 6, 213-232.

Zhang, P., Shao, G., Zhao, G., le Master, D., Parker, G., Dunning Jr. J., and Li Q.: 2000. China's Forest Policy for the $21^{\text {st }}$ Century. Science 288,. 2135-2136 
List of figures 
Table 1: Carbon emissions from forestry and energy sectors

\begin{tabular}{|c|c|c|c|c|c|c|}
\hline \multirow[t]{2}{*}{ Country } & \multirow{2}{*}{$\begin{array}{l}\text { National } \\
\text { emissions } \\
\text { in } 1990 \\
\text { (Mt C) }\end{array}$} & \multirow{2}{*}{$\begin{array}{c}{\mathrm{E} \& I^{\mathrm{a}}} \\
\text { sector in } \\
1990 \\
(\mathrm{Mt} \mathrm{C})\end{array}$} & \multicolumn{2}{|c|}{ Forestry sector } & \multirow{2}{*}{$\begin{array}{c}\text { Total } \\
\text { mitigation } \\
\text { potential (MP) } \\
(\mathrm{Mt} \mathrm{C})\end{array}$} & \multirow{2}{*}{$\begin{array}{c}\text { Ratio }^{b} \\
\text { MP/ E\&I }\end{array}$} \\
\hline & & & $\begin{array}{c}1990 \\
\text { (Mt C) }\end{array}$ & $\begin{array}{c}2020 \\
(\mathrm{Mt} \mathrm{C}) \\
\end{array}$ & & \\
\hline China & 507 & 556 & -61 & -105 & 9740 & 17 \\
\hline India & 146 & 141 & 1 & 21.0 & 8753 & 60 \\
\hline Indonesia & 38 & 38 & -94 & -106 & 1745 & 41 \\
\hline S. Korea & 62 & 66 & 1 & & 119 & 2 \\
\hline Mongolia & 5 & 3 & 1 & -0.3 & 317 & 83 \\
\hline Myanmar & -2 & 1 & -2 & -1.4 & 582 & 647 \\
\hline Pakistan & 20 & 17 & 2 & 19.0 & 161 & 9 \\
\hline Philippines & 35 & 10 & 22 & 0.6 & 2380 & 205 \\
\hline Thailand & 45 & 21 & 21 & 6.0 & 1259 & 54 \\
\hline Mexico & 127 & 74 & 53 & - & 4115 & 55 \\
\hline
\end{tabular}

Source: Sathaye and Ravindranath, 1998.

${ }^{a}$ Energy sector \& industrial processes in 1990

${ }^{\mathrm{b}}$ Ratio of mitigation potential in forestry to the annual emissions from the energy and industrial sector. The column represents the number of years the forestry sector could offset the country's emissions at 1990 levels.

Note: "Sum of Col. (2) and (3) need not equal col. (1) because the other sector emissions (agriculture, waste management, etc.) may not be included in the energy and forestry figures. 
Table 2: Summary of mitigation options by country

\begin{tabular}{|l|l|}
\hline Study Country & Options Included in the Study \\
\hline Brazil & Afforestation (Short- and Long-rotation) \\
\hline China & $\begin{array}{l}\text { Afforestation (Short and Long Rotation), } \\
\text { Agroforestry, } \\
\text { Regeneration } \\
\text { Bioenergy } \\
\text { Forest Protection }\end{array}$ \\
\hline India & $\begin{array}{l}\text { Afforestation (short and long rotation), } \\
\text { Regeneration, } \\
\text { Forest Protection }\end{array}$ \\
\hline Indonesia & $\begin{array}{l}\text { Forest plantation and timber estate, } \\
\text { Afforestation, } \\
\text { Reforestation, } \\
\text { Enhanced natural regeneration, } \\
\text { Forest Protection } \\
\text { Bioelectricity, } \\
\text { Reduced Impact Logging }\end{array}$ \\
\hline Philippines & $\begin{array}{l}\text { Afforestation (short and long rotation), } \\
\text { Natural regeneration, } \\
\text { Forest protection, } \\
\text { Bioenergy, }\end{array}$ \\
\hline Tanzania & $\begin{array}{l}\text { Long and Short rotation plantations, } \\
\text { Forest restoration, } \\
\text { Agroforestry, } \\
\text { Sustainable forest management } \\
\text { Bioenergy } \\
\text { Community short rotation woodlots } \\
\text { Long rotation softwood plantations } \\
\text { Long rotation hardwood plantations }\end{array}$ \\
\hline Mexico & \\
\hline
\end{tabular}


Table 3: Historical land-use patterns, deforestation, and forestation potential

\begin{tabular}{|c|c|c|c|c|c|}
\hline \multirow{3}{*}{ Country } & \multirow{3}{*}{$\begin{array}{l}\text { Total } \\
\text { Land } \\
\text { Area } \\
(\mathrm{k} \mathrm{ha})^{*}\end{array}$} & \multirow{3}{*}{$\begin{array}{c}\text { Forested } \\
\text { Area } \\
\text { (k ha) }\end{array}$} & \multirow{3}{*}{$\begin{array}{c}\text { Deforestation } \\
\text { Rate in Study } \\
\text { Area } \\
(\mathrm{k} \mathrm{ha} / \mathrm{yr})\end{array}$} & \multicolumn{2}{|c|}{ Land Suitable for Forestation } \\
\hline & & & & This Study & $\begin{array}{c}\text { Trexler \& } \\
\text { Haugen }\end{array}$ \\
\hline & & & & (k ha) & $(\mathrm{k} h \mathrm{~h})^{\mathrm{p}}$ \\
\hline Brazil & 845,700 & $390,000^{\mathrm{n}}$ & $1113-2906^{\mathrm{m}}$ & $85,000^{\top}$ & 85,000 \\
\hline China $^{a}$ & 963,296 & $158,941^{\mathrm{K}}$ & 60 & $31,953^{\mathrm{d}}$ & Not estimated \\
\hline India & 328,760 & $63,300^{\mathrm{b}}$ & $274^{\mathrm{C}}$ & 53,200 & 35,000 \\
\hline Indonesia $^{\mathrm{t}}$ & 192,401 & 104,500 & $750-1,500$ & $31,000^{\mathrm{e}}$ & 13,600 \\
\hline Mexico & 196,700 & 115,652 & $720^{1}$ & $21,000^{1}$ & 35,500 \\
\hline Philippines & 30,000 & 5,200 & $99^{h}$ & $4,400^{\mathrm{g}}$ & 8,000 \\
\hline Tanzania & 89,161 & 41,857 & 750 & $7,500^{\circ}$ & 11,100 \\
\hline TOTAL & $2,556,857$ & 837,593 & Not Applicabl. & 234,053 & 188,200 \\
\hline
\end{tabular}

* Source $=$ FAO Forest Resource Assessment 2000

${ }^{a}$ Includes forests with at least 20\% crown cover. Data are for 1998.

b - Data for 1995;

c_Data for 1995-97;

d-- Degraded lands in three study regions in 2000;

e-- Unproductive land, grasslands and critical lands;

f-- Annual average 1990-97 (includes transmigration, agricultural development, forest fire and shifting cultivation; excludes illegal logging).

g --Grassland areas, sub-marginal forests and brushlands;

h-- Annual average for 1995-1998 period;

i-- Early 1990s. Forest area includes semi-arid vegetation, which accounts for 66 Mha;;

j.- Degraded forest land;

$k$-Of the total forest land, forests in study area $=115.6$ million ha (three regions only);

I- Estimated potential for natural regeneration, farm forestry and plantations from Trexler and Haugen, 1995;

m.- From: Fearnside, P.M.: 1997b; Brazil (INPE), 1998: 1999.

"-- Forests and "cerrados" located in the Amazon region only.

${ }^{\circ}-3.5 \mathrm{mi}$. ha for short rotation community woodlots, and $2.5 \mathrm{mi}$. ha (50\% of the fallow area) for reforestation and $1.5 \mathrm{mi}$. ha for all other forestation including agroforestry, long rotation plantations, non-forest tree crops (wattle, rubber, oil palm, etc).

p-Figures from Trexler and Haugen, 1995. Estimated potential in regeneration, farm forestry and plantations between 1990 and 2040. 
Table 4: Land area scenarios for mitigation activities (Mha)

\begin{tabular}{|c|c|c|c|}
\hline Country & $2000-2012$ & $2000-2030$ & Mitigation Scenario Description \\
\hline $\begin{array}{l}\text { Brazil } \\
\text { Forestation }\end{array}$ & 6.8 & 19.8 & Based on Trexler and Haugen, 1995 \\
\hline $\begin{array}{l}\text { China } \\
\text { Forestation } \\
\text { Forest Protection }\end{array}$ & $\begin{array}{l}7.6 \\
5.1\end{array}$ & $\begin{array}{l}19.7 \\
13.5\end{array}$ & $\begin{array}{l}\text { Technical plan scenario }-60 \% \text { of the } \\
\text { government plan in the northeast, southeast } \\
\text { and southwest regions }\end{array}$ \\
\hline $\begin{array}{l}\text { India } \\
\text { Forestation } \\
\text { Forest Protection }\end{array}$ & $\begin{array}{c}412.2 \\
3.6\end{array}$ & $\begin{array}{c}29.5 \\
8.5\end{array}$ & $\begin{array}{l}\text { Sustainable forestry scenario that is designed } \\
\text { to meet } 2010 \text { biomass demand through } \\
\text { domestic LULUCF activities. }\end{array}$ \\
\hline $\begin{array}{l}\text { Indonesia } \\
\text { Forestation } \\
\text { Forest Protection }\end{array}$ & $\begin{array}{c}11.6 \\
0.5\end{array}$ & $\begin{array}{c}29.2 \\
1.1\end{array}$ & Same as the scenario for India. \\
\hline $\begin{array}{l}\text { Pliilippines } \\
\text { Forestation } \\
\text { Forest Protection }\end{array}$ & $\begin{array}{c}0.6 \\
0.07\end{array}$ & $\begin{array}{c}1.7 \\
0.13\end{array}$ & $\begin{array}{l}\text { Scenario assumes } 50 \% \text { of the rate of land } \\
\text { development under the government plan }\end{array}$ \\
\hline$\frac{\text { Mexico }}{\text { Forestation }}$ & 3.0 & 9.1 & $\begin{array}{l}\text { More effective and wider implementation of } \\
\text { baseline scenario activities to meet domestic } \\
\text { biomass demand. }\end{array}$ \\
\hline$\frac{\text { Tanzania }}{\text { Forestation }}$ & 0.4 & 1.7 & $\begin{array}{l}\text { Meets } 50 \% \text { of demand for woodfuel, sawlogs } \\
\text { and chiplogs, by } 2024 \text {. }\end{array}$ \\
\hline $\begin{array}{l}\text { Total } \\
\text { Forestation } \\
\text { Forest Protection }\end{array}$ & $\begin{array}{c}42.2 \\
9.2\end{array}$ & $\begin{array}{l}110.8 \\
23.2\end{array}$ & \\
\hline
\end{tabular}


Table 5: Carbon stock in mitigation and baseline scenarios (Mt C)

\begin{tabular}{|c|c|c|c|c|c|c|}
\hline \multirow[t]{2}{*}{ Country } & \multirow[t]{2}{*}{1990} & \multirow[t]{2}{*}{2000} & \multirow[t]{2}{*}{2012} & \multirow[t]{2}{*}{2030} & \multicolumn{2}{|c|}{$\begin{array}{l}\text { Cumulative Costs } \\
\text { (millions of } 1998 \text { US } \$ \text { ) }\end{array}$} \\
\hline & & & & & $2000-2012$ & $2000-2030$ \\
\hline Brazil & & & & & 590 & 1206 \\
\hline Baseline Scenario* & 0 & 0 & 0 & 0 & & \\
\hline Mitigation Scenario & 0 & 0 & 87 & 448 & & \\
\hline Increment & 0 & 0 & 87 & 448 & & \\
\hline China & & & & & 589 & 1390 \\
\hline Baseline Scenario & 9714 & 11115 & 11197 & 11321 & & \\
\hline Mitigation Scenario & 9714 & 11115 & 11236 & 11532 & & \\
\hline Increment & 0 & 0 & 39 & 211 & & \\
\hline India 录水水 & & & & & 615 & 1194 \\
\hline Baseline Scenario & 5610 & 5731 & 5727 & 5720 & . & \\
\hline Mitigation Scenario & 5610 & 5731 & 6053 & 6680 & & \\
\hline Increment & 0 & 0 & 326 & 960 & & \\
\hline Indonesia & & & & & 4950 & 8601 \\
\hline Baseline Scenario & 18680 & 17450 & 16500 & 16140 & & \\
\hline Mitigation Scenario & 18680 & 17450 & 17228 & 18650 & & \\
\hline Increment & 0 & 0 & 728 & 2510 & & \\
\hline Philippines & & & & & 82 & 151 \\
\hline Baseline Scenario & 1300 & 1130 & 965 & 805 & & \\
\hline Mitigation Scenario & 1300 & 1135 & 990 & 881 & & \\
\hline Increment & 0 & 5 & 25 & 76 & & \\
\hline Mexico*水 & & & & & - & - \\
\hline Baseline Scenario & 24029 & 23397 & 22927 & 22586 & & \\
\hline Mitigation Scenario & 24029 & 23434 & 23520 & 24376 & & \\
\hline Increment & 0 & 37 & 593 & 1790 & & \\
\hline Tanzania & & & & & 49 & 165 \\
\hline Baseline Scenario & 128 & 128 & 128 & 128 & & \\
\hline Mitigation Scenario & 128 & 130 & 181 & 332 & & \\
\hline Increment & 0 & 2 & 53 & 204 & & \\
\hline Total & & & & & 6875 & 12707 \\
\hline Baseline Scenario & 59461 & 58951 & 57444 & 56700 & & \\
\hline Mitigation Scenario & 59461 & 58995 & 59208 & 62451 & & \\
\hline Increment & 0 & 44 & 1764 & 5751 & & \\
\hline Increment + Brazil & & & 1851 & 6199 & & \\
\hline
\end{tabular}


Notes: Increment $(T)=$ Mitigation $(T-2000)-$ Baseline $(T-2000)$ NA = Not applicable

* Baseline carbon stock for Brazil assumed to be at equilibrium for the areas where afforestation will take place.

*** For India, cost of forest protection is not included. The India study envisions a national program to halt deforestation that otherwise would have converted virtually all forests to other uses by 2030 . The estimated cost for such a program is large, and amounts to over $\$ 10$ billion by 2030 , an amount which is not included in the figure in the Table.

**** For Mexico, only life cycle cost was given without the year of occurrence, as such discounting could not be done. 
Table 6: China - Land area for mitigation activities in $2000\left(10^{3} \mathrm{ha}\right)$

\begin{tabular}{|c|c|c|c|c|c|}
\hline \multirow[t]{2}{*}{ Activities } & \multicolumn{5}{|c|}{ Land Areas in regions for Activities } \\
\hline & Northeast & Southeast & Southwest & Total & Percent \\
\hline Short rotation ${ }^{\prime \prime}$ & 681 & 3789 & 2446 & 6916 & $9 \%$ \\
\hline Long rotation ${ }^{\text {I) }}$ & 1135 & 3789 & 3057 & 7981 & $10 \%$ \\
\hline Regeneration ${ }^{\text {II }}$ & 2270 & 5305 & 4891 & 12466 & $16 \%$ \\
\hline $\begin{array}{l}\text { Forest } \\
\text { Conservation }^{2)}\end{array}$ & 4057 & 5682 & 3735 & 13474 & $17 \%$ \\
\hline Agroforestry ${ }^{3)}$ & 9743 & 16141 & 6599 & 32483 & $42 \%$ \\
\hline Bioenergy ${ }^{I)}$ & 483 & 2273 & 1834 & 4590 & $6 \%$ \\
\hline Totals & 18369 & 36979 & 22562 & 77910 & $100 \%$ \\
\hline
\end{tabular}

Notes:

1) Calculated based on land available and relative proportion in 1990, forest area (1989-1993) (CMOF, 1994), forest area (1994-1998) issued by CMOF in 1999 and long-term forestry plan (CMOF, 2000).

2) Forest conservation area refers to that of existing dense forests. Figures in the table are calculated based on forest nature-reserve planning in long-term forestry plan (CMOF, 2000) mentioned above and actual regional proportion of nature reserves in 1993 and 1997

3) Land for agroforestry development is from the agricultural land, and was estimated to be $60 \%$ of the total arable area. 
Table 7: Land requirements, potential carbon benefits and investment costs in Agroforestry versus other mitigation options in China (2000-2030)

\begin{tabular}{|c|c|c|c|c|c|}
\hline Region & Mitigation Option & $\begin{array}{c}\text { Cumulative } \\
\text { Area } \\
\text { Increment } \\
(\mathrm{k} \text { ha }) \\
\end{array}$ & $\begin{array}{c}\text { Carbon } \\
\text { Pool } \\
\text { increment } \\
\text { (Mt C) }\end{array}$ & $\begin{array}{c}\text { Percent of } \\
\text { C-pool in } \\
\text { agroforestry }\end{array}$ & $\begin{array}{c}\text { Investment } \\
\text { costs } \\
(\$ / \mathrm{ha})^{*}\end{array}$ \\
\hline \multirow[t]{3}{*}{ Northeast } & All other options & 3151 & 601.0 & & $380-11400$ \\
\hline & Agroforestry & 7192 & 107.8 & $15 \%$ & 80 \\
\hline & Sub-total & & 708.8 & & \\
\hline \multirow[t]{3}{*}{ Southeast } & All other options & 18007 & 601.6 & & $290-11420$ \\
\hline & Agroforestry & 7488 & 112.3 & $16 \%$ & 140 \\
\hline & Sub-tota1 & & 713.9 & & \\
\hline \multirow[t]{3}{*}{ Southwest } & All other options & 9195 & 598.1 & & $280-11380$ \\
\hline & Agroforestry & 4820 & 72.3 & $11 \%$ & 100 \\
\hline & Sub-total & & 670.4 & & \\
\hline \multirow[t]{2}{*}{ Total } & All other options & 30353 & 1800.7 & & \\
\hline & Agroforestry & 19500 & 292.4 & $14 \%$ & 108 \\
\hline Total China & $\begin{array}{l}\text { All Mitigation } \\
\text { Options }\end{array}$ & 49853 & 2093.1 & & \\
\hline
\end{tabular}

Agroforestry C-density (tC/ha) is 14.99 compared to $59.33 \mathrm{tC} /$ ha for all other options.

* The high values are from the bioenergy programs of which cost includes that of generation equipment and annual maintenance, allocated on a per hectare basis. 
Table 8: Mexico - Net Carbon Sequestration (Mitigation-Reference Scenario) 1990-2030 (kt C)

\begin{tabular}{|c|c|c|c|c|}
\hline Land Use/Cover Class & 2000 & 2008 & 2012 & 2030 \\
\hline \multicolumn{5}{|l|}{ Unmanaged forests } \\
\hline Temperate conifer & 7,944 & $-156,119$ & $-210,086$ & $-496,351$ \\
\hline Temperate broadleaf & 6,510 & 40,650 & 61,541 & 146,479 \\
\hline Tropical evergreen & 17,337 & 107,929 & 157,237 & 297,955 \\
\hline Tropical deciduous & 19,569 & 111,431 & 161,469 & 339,915 \\
\hline Semi-arid forests & 1,989 & 12,935 & 12,622 & -464 \\
\hline Degraded forest lands & $-2,777$ & $-101,612$ & $-194,991$ & $-632,390$ \\
\hline \multicolumn{5}{|l|}{ Plantations } \\
\hline Long rotation & 0 & 3,520 & 8,263 & 6,783 \\
\hline Short rotation & 0 & 5,630 & 19,525 & 78,949 \\
\hline Restoration Plantations & 0 & 89,627 & 165,499 & 565,377 \\
\hline Bioenergy Plantations & 0 & 25,668 & 61,946 & 263,005 \\
\hline \multicolumn{5}{|l|}{ Managed forests } \\
\hline Temperate conifer & -293 & 187,461 & 260,293 & 620,081 \\
\hline Tropical evergreen & 0 & 0 & 0 & 0 \\
\hline \multicolumn{5}{|l|}{ Protected forests } \\
\hline Temperate & 0 & 31,568 & 55,494 & 180,051 \\
\hline Tropical evergreen & 0 & 26,233 & 45,019 & 141,493 \\
\hline Tropical deciduous & 0 & 44,864 & 77,424 & 209,097 \\
\hline Wetlands & 0 & 0 & 0 & 0 \\
\hline Semi-arid forests & 0 & 5,938 & 19,494 & 99,433 \\
\hline \multicolumn{5}{|l|}{ Other uses } \\
\hline Agriculture & $-13,296$ & $-71,971$ & $-108,129$ & $-290,958$ \\
\hline Pasture & $-15,576$ & $-126,702$ & $-195,392$ & $-468,556$ \\
\hline Agroforestry & 15,939 & 63,873 & 92,622 & 270,969 \\
\hline TOTAL & 37,348 & 300,921 & 489,099 & $1,304,549$ \\
\hline
\end{tabular}


Table 9: Mexico - Costs of Selected Mitigation Options

\begin{tabular}{|c|c|c|c|c|c|c|c|c|c|}
\hline $\begin{array}{l}\text { Forest } \\
\text { Mitigation } \\
\text { Option }\end{array}$ & $\begin{array}{l}\text { Invest- } \\
\text { ment } \\
(\$ / \text { ha })\end{array}$ & $\begin{array}{c}\text { Mainte- } \\
\text { nance } \\
(\$ / \text { ha })\end{array}$ & $\begin{array}{l}\text { Moni- } \\
\text { toring } \\
(\$ / \text { ha })\end{array}$ & $\begin{array}{l}\text { Life } \\
\text { Cycle } \\
\text { cost } \\
(\$ / \text { ha })\end{array}$ & $\begin{array}{l}\text { NPV } \\
(\$ / \text { ha })\end{array}$ & $\begin{array}{l}\text { Project } \\
\text { Cycle/ } \\
\text { Rotatio } \\
\text { n (yrs) }\end{array}$ & $\begin{array}{l}\text { Carbon } \\
\text { Density } \\
\text { (t C/ha) }\end{array}$ & \begin{tabular}{|c} 
Increment \\
in carbon \\
stock \\
(t C/ha)
\end{tabular} & $\begin{array}{c}\text { Carbon } \\
\text { Cost } \\
(\$ / t C)\end{array}$ \\
\hline $\begin{array}{l}\text { Short } \\
\text { Rotation } \\
\text { Plantation }\end{array}$ & 415 & 1,708 & 8 & 2,131 & 497 & 7 & 154 & 61 & 35.1 \\
\hline $\begin{array}{l}\text { Long } \\
\text { Rotation } \\
\text { Plantation }\end{array}$ & 394 & 998 & N/A. & 1,392 & 5,780 & 20 & 191 & 98 & 14.2 \\
\hline $\begin{array}{l}\text { Restoration } \\
\text { Plantation }\end{array}$ & 438 & 391 & 8 & 837 & N/A. & 50 & 180 & 87 & 9.6 \\
\hline $\begin{array}{l}\text { Agroforestry } \\
\text { Systems }\end{array}$ & 173 & 101 & 0.00 & 274 & $\mathrm{~N} / \mathrm{A}$. & 16 & $128-159$ & $27-66$ & $4.1-10.0$ \\
\hline $\begin{array}{l}\text { Temperate } \\
\text { Forest } \\
\text { Management }\end{array}$ & 5 & 57 & 32 & 94 & 78 & 50 & 234 & 141 & 0.7 \\
\hline Bioenergy & 1,224 & 1,707 & 8 & 2,940 & 345 & 7 & 281 & 188 & 15.6 \\
\hline
\end{tabular}


Table 10: Vietnam - COMAP output for 4 forestry mitigation options

\begin{tabular}{|l|c|c|c|c|c|c|}
\hline \multirow{2}{*}{ Category } & $\begin{array}{c}\text { Incremental } \\
\text { Carbon } \\
\text { stock }\end{array}$ & $\begin{array}{c}\text { Mitigation } \\
\text { Potential }\end{array}$ & \multicolumn{2}{|c|}{$\begin{array}{c}\text { Present Value of } \\
\text { Benefit }\end{array}$} & \multicolumn{2}{|c|}{$\begin{array}{c}\text { Present Value of } \\
\text { Cost }\end{array}$} \\
\cline { 2 - 7 }$(\mathrm{Mt} \mathrm{C})$ & $(\mathrm{t} \mathrm{C/ha)}$ & $(\$ / \mathrm{tC})$ & $(\$ /$ ha $)$ & $(\$ / \mathrm{t} \mathrm{C})$ & $(\$ /$ ha $)$ \\
\hline $\begin{array}{l}\text { Enhanced natural } \\
\text { regeneration }\end{array}$ & 87.3 & 47.2 & 1.27 & 55.55 & 1.04 & 45.42 \\
\hline Reforestation & 209.6 & 107.3 & 5.51 & 577.10 & 3.35 & 351.19 \\
\hline Natural forest protection & 862.5 & 132.7 & 0.69 & 91.04 & 0.33 & 43.45 \\
\hline Scattered trees* & 78.7 & 47.7 & 9.25 & 404.25 & 1.35 & 59.17 \\
\hline Total Potential & 1238.10 & & & & & \\
\hline Weighted Average & & 116.97 & 2.09 & 190.73 & 0.96 & 96.69 \\
\hline
\end{tabular}

Source: UNEP 1998 - Vietnam Final Report

* Most of the scattered trees option constitute of farmers and communities planting in agricultural lands. 
Table 11: Tanzania - Woodfiel Plantations and Agroforestry for Carbon sequestration (Costs and benefits in 1986 USD)

\begin{tabular}{|c|c|c|c|c|c|}
\hline & $\begin{array}{l}\text { Govt. Fuel } \\
\text { Plantation }\end{array}$ & $\begin{array}{c}\text { Govt./ } \\
\text { Public } \\
\text { Partnership }\end{array}$ & $\begin{array}{l}\text { Eucaly- } \\
\text { ptus \& } \\
\text { Maize }\end{array}$ & $\begin{array}{l}\text { Boundary } \\
\text { Gravellia } \\
\text { \& Maize }\end{array}$ & $\begin{array}{l}\text { Inter- } \\
\text { cropping } \\
\text { Gravellia } \\
\& \text { Maize }\end{array}$ \\
\hline Project Life (Yrs) & 6 & 6 & 6 & 20 & 20 \\
\hline Initial Investment & 287 & 200 & & & \\
\hline Other Cost $Y_{r} 1$ & 53 & & & & \\
\hline $\operatorname{Yr} 2$ & 20 & 13 & 33 & 27 & 27 \\
\hline $\begin{array}{l}\text { Revenues from } \\
\text { Fuelwood only }\end{array}$ & 600 & 600 & 187 & 213 & 260 \\
\hline $\begin{array}{l}\text { Sequestered } C \\
\text { (t C/ ha })\end{array}$ & 47 & 47 & 15 & 23 & 73 \\
\hline $\mathrm{NPV}(\$ / \mathrm{tC})$ & -0.43 & 3.40 & 4.67 & 0.29 & 0.27 \\
\hline
\end{tabular}

Source: Makundi and Okiting'ati, 1995 


\section{List of Figures:}

Figure 1: Forestry mitigation poential (Brazil, China, India, Indonesia, Mexico, Philippines and Tanzania) 
Figure 1. Forestry Mitigation Potential

(Brazil, China, India, Indonesia, Mexico, Philippines and Tanzania)

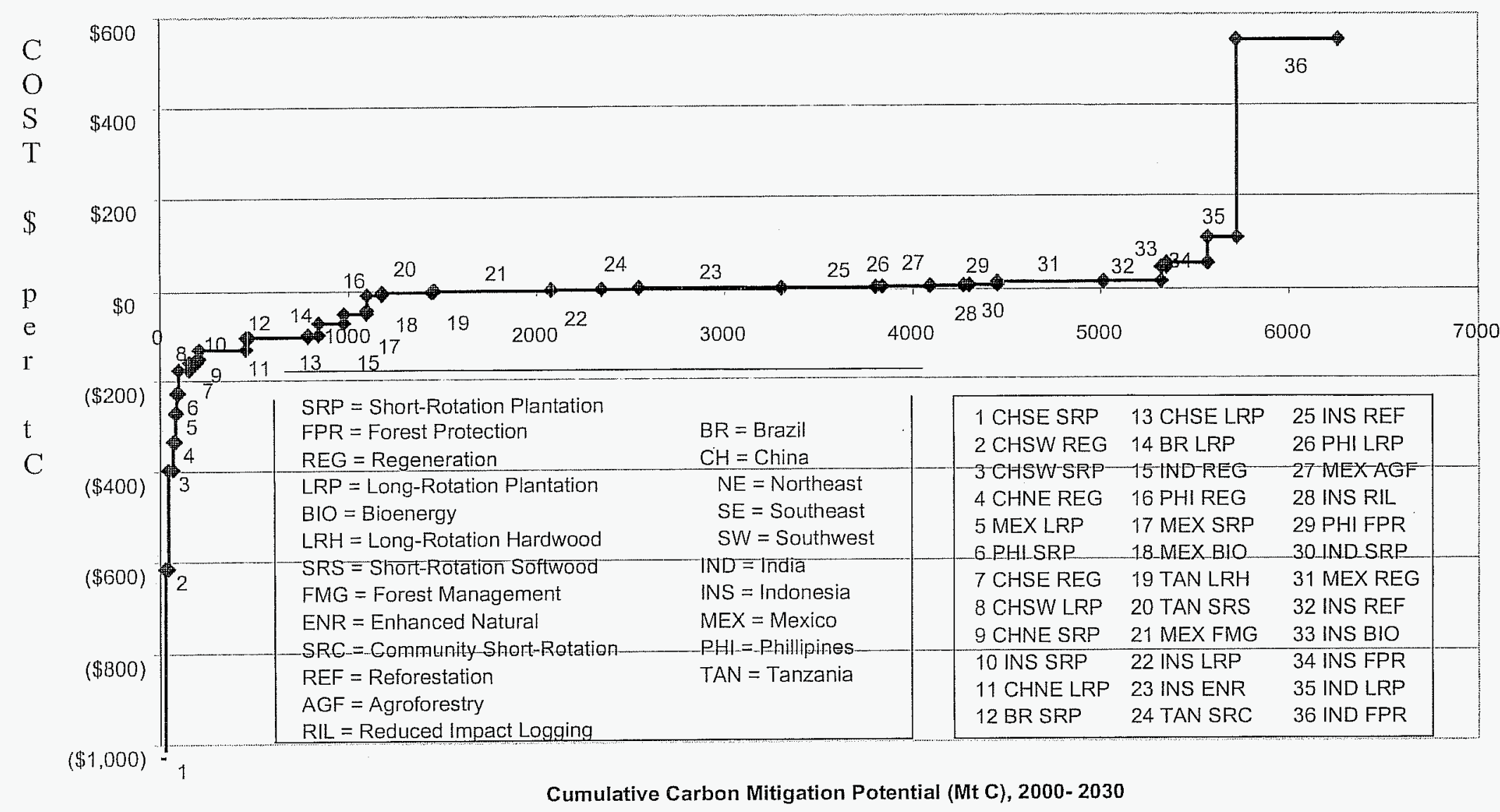

